\title{
CORPORATE PROFILE, PERFORMANCE AND GREEN SUPPLY CHAIN MANAGEMENT: A RESEARCH AGENDA
}

\section{FÁBIO YTOSHI SHIBAO}

$\mathrm{PhD}$ in Philosophy in Business Administration from the Applied and Social Sciences Center, Universidade Presbiteriana Mackenzie (UPM).

Full Professor at the Master in Business Administration Program, Universidade Nove de Julho (Uninove).

Av. Francisco Matarazzo, 612, Água Branca - SP - Brasil - CEP 05001-100

E-mail: fabio.shibao@gmail.com

\section{GERALDO CARDOSO DE OLIVEIRA NETO}

$\mathrm{PhD}$ in Industrial Engineering and Business Administration,

Universidade Nove de Julho (Uninove).

Full Professor at the Industrial Engineering Program,

Universidade Nove de Julho (Uninove).

Av. Francisco Matarazzo, 612, Água Branca - SP - Brasil - CEP 05001-100

E-mail: geraldo.prod@gmail.com

\section{FLAVIA CRISTINA DA SILVA}

Master's Degree in Business Administration,

Universidade Nove de Julho (Uninove).

Av. Francisco Matarazzo, 612, Água Branca - SP - Brasil - CEP 05001-100

E-mail: flacrisil@yahoo.com.br

\section{EDUARDO CABRINI POMPONE}

Master's Degree student in Smart and Sustainable Cities,

Universidade Nove de Julho (Uninove).

Av. Francisco Matarazzo, 612, Água Branca - SP - Brasil - CEP 05001-100

E-mail: eduardo.pompone@gmail.com 


\section{ABSTRACT}

Purpose: To evaluate the universe of published articles that propose frameworks about the relationship between green supply chain management (GSCM) and performance in the period from 1995 to 2014, in order to propose a conceptual model that can be applied to future studies, considering the green profile besides the practices of GSCM and performance.

Originality/gap/relevance/implications: The investigation revealed a lack of relationship among the organizations' profile, its environmental, economic and operational performance and GSCM practices.

Key methodological aspects: The relationship among constructs was established through bibliometric analysis obtained in the models/frameworks of GSCM practices and performance extracted from the databases "ProQuest", "EBSCO", "JSTOR", "Web of Science" and "Scopus". Further, the content analysis and network analysis were then performed. Summary of key results: GSCM internal and external practices, environmental performance, economic performance and operational performance were revealed as main topics addressed in GSCM. Moreover, it was noted that studies on internal practices prevailed over those addressed to other practices.

Key considerations/conclusions: The models studied did not consider whether the corporate green profile could improve the performance of the organization. Therefore, they did not simultaneously measure environmental, economic and operational performance. It was concluded that the addition of the green profile in conjunction with GSCM practices and performance allows for a more in-depth analysis of the degree of a company's involvement with GSCM, as well as its intended objectives and results achieved in the future. 


\section{KEYWORDS}

Bibliometric Analysis. Framework. Green Profile. Green Supply Chain Management. Performance.

\section{INTRODUCTION}

The effectiveness of the productive sector has been due to the implementation of several tools such as total quality management, process management and reengineering, which has led organizations to a significant increase in the quality of their products and services. The traditional supply chain is based on total cost and profitability.

The environmental impact of previously neglected operations, such as the environmental problems caused by global warming and environmental degradation, has affected the population's survival conditions (Wang \& Gupta, 2011). Moreover, stringent legislation has been enacted, such as Brazilian law 12305/2010 of the National Policy on Solid Waste (Brazil, 2010).

One of the consequences of the publication of this law was the requirement to predict the need for the implementation of reverse logistics (Brazil, 2010). There was intensification of research on the adoption of GSCM practices due to Brazilian environmental legislation and international directives (Jabbour, Azevedo, Arantes \& Jabbour, 2013).

GSCM includes loss reduction, recycling, supplier development, buyer performance, reward and risk sharing, adoption of cleaner technologies, adjustments to legislation, reuse of materials, water and energy economy, use of environmentally friendly inputs, lean production processes, environmental commitment of participants in the supply chain and reverse logistics (Zhu, Tian \& Sarkis, 2012).

The GSCM theme is still embryonic in Brazil. Pimenta, Gouvinhas and Evans (2012) presented a generic model related to eco-efficiency strategies for mapping environmental impacts and economic evaluation in the manufacturers, importers, distributors and dealers of agrochemicals, batteries, lubricants, fluorescent lamps and electronic products. Larentis, Giovanella and Cislaghi (2013) developed a conceptual model that addressed the relationship between clusters and sustainability without focusing on any specific segment. 
Thus, the aim of this research was to evaluate articles that proposed models/frameworks of the relationship between GSCM and performance as well as propose a conceptual model that could be applied for future studies, considering not only the practices of GSCM and performance but also the green profiles of companies.

Therefore, in addition to this introduction, the paper presents four other sections: theoretical backgrounds, methodological procedures, results and discussion and concluding remarks.

\section{THEORETICAL BACKGROUNDS}

This section shows the theoretical reference on green supply chain management and practices as well as economic, financial and operational performances and corporate profiles.

\subsection{GREEN SUPPY CHAIN MANAGEMENT (GSCM)}

Supply chain management (SCM) consists of coordinating traditional business strategies and functions among companies in order to optimize the performance of the entire chain, according to Mentzer et al. (2001).

Large scale production has been associated with environmental degradation and scarce resources (Fiksel, 1996). Therefore, stakeholders aiming the company's development have forced the companies to engage in environmentally responsible activities (Zhu, Sarkis, \& Lai, 2013).

In the concept proposed by Srivastava (2007), GSCM is understood as the incorporation of environmental aspects into all SCM dimensions and interfaces, including development and manufacturing of the product, outsourcing of services, transportation and delivery of the product to the final customer, and product management after the end of the product's useful life.

The main differences between SCM and GSCM, highlighted by Ho, Shalishali, Tseng and Ang (2009), refer to the objective, type of interaction with the environment, supplier selection criteria, cost and price pressure, and chain speed and flexibility. SCM is economically focused, has a high impact on the environment, selects its suppliers based on costs, which generates pressure among the players for low prices, and brings great flexibility and volatility to the chain. However, GSCM divides its focus between economic and environmental performance, proposes to cause low impacts to the environment and establishes long term relationships among the actors based on environmental commitment. 
Environmental practices contribute to the improvement of quality, according to Zhu and Sarkis (2004). Environmental activities in supply chain management related to the reduction of consumption of resources and raw materials, prevention of pollution, recycling and adequate disposal of waste, were considered GSCM practices (Vanchon \& Klassen, 2006).

GSCM is divided into internal practices, or intra-organizational categories, when the direct control is with the organization and involves internal stakeholders, and GSCM external practices, or inter-organizational categories, when they involve operations with external stakeholders (Zhu, Sarkis, \& Lai, 2008).

Several aspects of GSCM require further elucidation, such as the imbalance between the adoption of internal and external practices and the conflicting results associated with GSCM practices (Zhu et al., 2005). Moreover, the fact of having insufficient evidence between the implementation of GSCM and the environmental, economic or operational performance (Zhu et al., 2005) constitutes a barrier to the implementation of GSCM.

\subsection{PERFORMANCE}

Economic performance is a priority for top management, which justifies the implementation of GSCM practices since the benefits derived from the economic performance of organizations, such as increased trust and cooperation, have been the object of study (Hernandez, Marins, \& Castro, 2012; Jamishidi, Ghomi, \& Karimi, 2012; Porter \& Van der Linde, 1995; Rao \& Holt, 2005; Seuring \& Müller, 2008; Srivastava, 2007; Zhu, Sarkis, \& Lai, 2012).

The environmental performance of an organization includes the results obtained with the management of its environmental aspects, measured by indicators such as compliance with legal and customer requirements and costs associated with environmental compliance (ABNT, 2004, 2005; Chan, He, Chan, \& Wang, 2012; Olugu, Wong, \& Shaharoun, 2011; Sawadogo \& Anciaux, 2011).

Regarding operational performance, the influence of GSCM is considered to extend from the monitoring of legislation to the implementation of practices, such as increasing the quantity of goods delivered on time, reducing inventory levels, reducing the scrap rate, increasing product quality, increasing productivity, and improving capacity, environmental management systems, pollution control, reduction of resource consumption, and reuse and recycling of products (Dou, Zhu, \& Sarkis, 2014; Jabbour, Jabbour, Govindan, Kannan, \& Arantes, 2014; Larentis et al., 2013; Srivastava, 2007; Wu, 2013; Zhu, Sarkis, \& Lai, 2007). 


\subsection{CORPORATE PROFILE}

Organizations' attitudes and commitments to environmental management are influenced by economic and market aspects, especially regarding the rational use of resources, eco-efficient production processes, conscious consumption and adequate waste destination (Shibao, 2011).

Self-regulation or corporate pro-activity is a position that emerges from the general administration area towards several specific sectors. Moreover, in relation to environmental management, it is supposed to obtain a competitive advantage by incorporating environmental issues into business strategies at all decision levels, since planning to product execution with the inclusion of monitoring and prevention metrics, in anticipation of the regulations and trends (Ninlawan, Seksan, Tossapol, \& Pilada, 2010; Porter \& Van der Linde, 1995; Shibao, 2011; Singh, Murty, Gupta, \& Dikshit, 2008; Zhu \& Sarkis, 2004; Zhu, Geng, Fujita, \& Hashimoto, 2010).

From this perspective, operational management supported by the efficiency of environmental performance contributes to reduction of financial risk; besides, it proposes to organizations promising economic scenarios (Hoffman, 2000).

However, the model of environmental reactivity or compliance is developed in order to comply with applicable environmental legislation with the aim of protecting the organization's reputation, which indicates a greater concern to avoid costs arising from sanctions and fines than to implement consistent environmental policies regarding the interests of society (Lau \& Ragothaman, 1997; Lee, 2008; Lee \& Klassen, 2008).

\section{METHODOLOGICAL PROCEDURES}

The research method consisted of bibliometric analysis to quantify the scientific production of the existing models and framework, which deal with the relationship among GSCM, green profiles and performance (Cooper \& Lindsay, 1998). The bibliometric analysis is relevant to indicate directions and strategies for future research, according to Leite Filho (2006).

The constructs presented in Figure 1 directed this study with the intention to understand how they were related in the sampled works and, from these results, to draw a conceptual model for a future research agenda. 


\section{(Figure 1) \\ CONSTRUCTS}

\begin{tabular}{ll}
\multicolumn{1}{c}{ Constructs } & \multicolumn{1}{c}{ References } \\
\hline GSCM & Lin (2013); Zhu and Sarkis (2004); Zhu et al. (2008); Zhu et al. (2013) \\
\hline Internal GSCM practices & Lee, Kim and Choi (2012); Mirhedayatian, Azadi and Saen (2014) \\
\hline External GSCM practices & Koh, Gunasekaran, and Tseng (2012); Lee and Klassen (2008) \\
\hline Green Investments & Green, Zelbst, Meacham, and Bhadauria (2012); Mitra and Datta (2014) \\
\hline Eco-design & Green, Zelbst, Bhadauria, and Meacham (2012); Pimenta et al., (2012) \\
\hline Reverse logistics & Büyüközkan and Cifçi (2012); Felice et al. (2012) \\
\hline Environmental performance Chan et al. (2012); Olugu et al. (2011); Sawadogo and Anciaux (2011) \\
\hline Economic performance & Hernandez et al. (2012); Jamshidi et al. (2012); Seuring and Müller (2008) \\
\hline Operational performance & Dou et al. (2014); Larentis et al. (2013); Srivastava (2007); Wu (2013) \\
\hline Proactive profile & Ninlawan et al. (2010); Singh et al. (2008); Zhu and Sarkis (2004) \\
\hline Reactive profile & Lee (2008), Lee and Klassen (2008) \\
\hline
\end{tabular}

Source: Elaborated by the authors.

\subsection{DATA COLLECTION}

The databases searched were "ProQuest", "EBSCO", "JSTOR", "Web of Science" and "Scopus" with the keywords ("model" AND "green supply chain" AND "performance") and ("framework" AND "green supply chain" AND "performance") when they were in the title, keywords or abstract in the article. This initial survey resulted in 63 articles, considering the period from 1995 until 2014. Only 43 articles proposed models/frameworks of the relationship between GSCM and performance. The research consisted of verifying whether or not the constructs of the model were derived from theory and later tested in the field. Moreover, theoretical tests were carried out. Verification of the 63 articles was carried out and checked by two researchers independently to minimize errors (Hayes \& Krippendorff, 2007) and resulted in the 43 papers that will be further analyzed and discussed.

The sample was processed through content analysis to identify the constructs addressed, the methodologies used and the countries surveyed. The content analysis performed in this work was of documentary origin, which 
aimed, through a set of operations (coding and categorization), to represent the content of articles for knowledge inference (Bardin, 1986).

\subsection{DATA ANALYSIS}

The categorization of data extracted from the articles was established by lexical means, in which the words were classified according to their meaning, with pairing and grouping, after data coding (Bardin, 1986). The variables analyzed in the existing models were as follows: authors, methodology, constructs and variables of the model, which allowed to performing social network analysis through the UCINET-DRAW software to generate indicators and to establish graphs (Borgatti, 2002).

Thus, it was possible to develop two graphs. One elucidates the relationship between authors and methodology and another shows the relationships between authors and constructs.

The bibliometric indicators of the social networks used were as follows: 1. Degree of Centrality (DC), which aimed to evaluate the number of loops an element has in relation to the others in the network (Wasserman \& Faust, 1994). If an element presented a greater number of connections, it was more centralized (Scott, 2000). 2. The measure of cohesion was aimed to identify the strongest links in relation to the research universe (De Nooy et al., 2005).

The aspects of GSCM and the performance variables studied in these works are presented in the following sections. Moreover, the so-called "green profile" variables are also presented, which are shown under two perspectives: reactive and proactive. In the reactive approach, companies allocate the minimum resources for environmental management and some initiatives to reduce environmental impact on production (Jabbour et al., 2013; Lee, 2008; Lee \& Klassen, 2008; Lin, 2013; Mitra \& Datta, 2014). In the proactive approach, companies begin to anticipate new environmental laws, for example, by allocating resources for recycling (Singh et al., 2008).

\section{RESULTS AND DISCUSSION}

The total relationships of the constructs as well as authors and methodologies addressed by the respective authors can be seen in Table 1. The total relations measure the number of connections between the nodes 
of the network, whereas the individual relations quantify the number of published articles.

\section{(Table 1)}

TOTAL AND INDIVIDUAL RELATIONSHIPS OF THE CONSTRUCTS, METHODOLOGIES AND AUTHORS

\begin{tabular}{|c|c|c|c|c|}
\hline & $\begin{array}{c}\text { Total } \\
\text { Relationships }\end{array}$ & $\begin{array}{l}\text { Degree of } \\
\text { Centrality Total } \\
\text { Relationships }\end{array}$ & $\begin{array}{l}\text { Relationships } \\
\text { Individuals }\end{array}$ & $\begin{array}{l}\text { Degree of } \\
\text { Centrality } \\
\text { Individuals }\end{array}$ \\
\hline \multicolumn{5}{|c|}{ Degree of Centrality of the constructs } \\
\hline GSCM internal practices & 39.000 & 11.017 & - & - \\
\hline Environmental performance & 32.000 & 9.040 & - & - \\
\hline GSCM external practices & 24.000 & 6.780 & - & - \\
\hline Economic performance & 20.000 & 5.650 & - & - \\
\hline Operational performance & 10.000 & 2.825 & - & - \\
\hline Reverse logistic & 9.000 & 2.542 & - & - \\
\hline Green investments & 7.000 & 1.977 & - & - \\
\hline Eco-design & 6.000 & 1.695 & - & - \\
\hline Corporate reactivity & 5.000 & 1.412 & - & - \\
\hline Corporate proactivity & 1.000 & 0.282 & - & - \\
\hline \multicolumn{5}{|l|}{ Methodologies } \\
\hline Survey & 13.000 & 3.672 & - & - \\
\hline Math simulation & 10.000 & 2.825 & - & - \\
\hline Case study & 10.000 & 2.825 & - & - \\
\hline Multiply cases & 6.000 & 1.695 & - & - \\
\hline Theoretical descriptive research & 4.000 & 1.130 & - & - \\
\hline \multicolumn{5}{|l|}{ Authors who most published } \\
\hline Zhu & 18.000 & 5.085 & 3 & 0.847 \\
\hline Sarkis & 6.000 & 1.695 & 3 & 0.847 \\
\hline Green & 17.000 & 4.802 & 2 & 0.565 \\
\hline Chan & 11.000 & 3.107 & 2 & 0.565 \\
\hline
\end{tabular}




\section{(Table 1 (Conclusion)) \\ TOTAL AND INDIVIDUAL RELATIONSHIPS OF THE CONSTRUCTS, METHODOLOGIES AND AUTHORS}

\begin{tabular}{lcccc}
\hline & $\begin{array}{c}\text { Total } \\
\text { Relationships }\end{array}$ & $\begin{array}{c}\text { Degree of } \\
\text { Centrality Total } \\
\text { Relationships }\end{array}$ & $\begin{array}{c}\text { Relationships } \\
\text { Individuals }\end{array}$ & $\begin{array}{c}\text { Degree of } \\
\text { Centrality } \\
\text { Individuals }\end{array}$ \\
\hline Authors who most published & 11.000 & 3.107 & 2 & 0.565 \\
\hline Felice & 8.000 & 2.260 & 2 & 0.565 \\
\hline Chiou & 6.000 & 1.695 & 2 & 0.565 \\
\hline Bhadauria & 6.000 & 1.695 & 2 & 0.565 \\
\hline Meacham & 5.000 & 1.412 & 2 & 0.565 \\
\hline Zettice & 6.000 & 1.695 & 2 & 0.565 \\
\hline Petrillo & 4.000 & 1.130 & 2 & 0.565 \\
\hline
\end{tabular}

Source: Elaborated by the authors.

The authors' network in relation to the research methodologies is elucidated in Figure 1. It is possible to notice that the methodologies most used by the authors to develop and/or test the models were as follows: Survey (13 ties and DC 3.672), Math simulation (10 ties and DC 2.825) and Case study (10 ties and DC: 2.825 ). It was also possible to notice that the less used methodologies were as follows: Multiply cases (six ties and DC: 1.695) and Theoretical descriptive research (four ties and DC: 1.130), according to Table 1.

This result shows in most of the studies that the model was developed based on theory and later tested through survey, mathematical simulation and case study, denoting an adequate construction and test of the models in the field. However, it has been pointed out that there is little descriptive theoretical research because the theme is closely associated with practice.

The authors who developed the most models/frameworks were as follows: Zhu and Sarkis with three articles each, as well as Green, Chan, Felice, Chiou, Bhadauria, Meacham, Lettice, Zelbst and Petrillo, with two publications. 


\section{(Figure 2)}

\section{AUTHORS' NETWORK IN RELATION TO RESEARCH METHODOLOGIES}

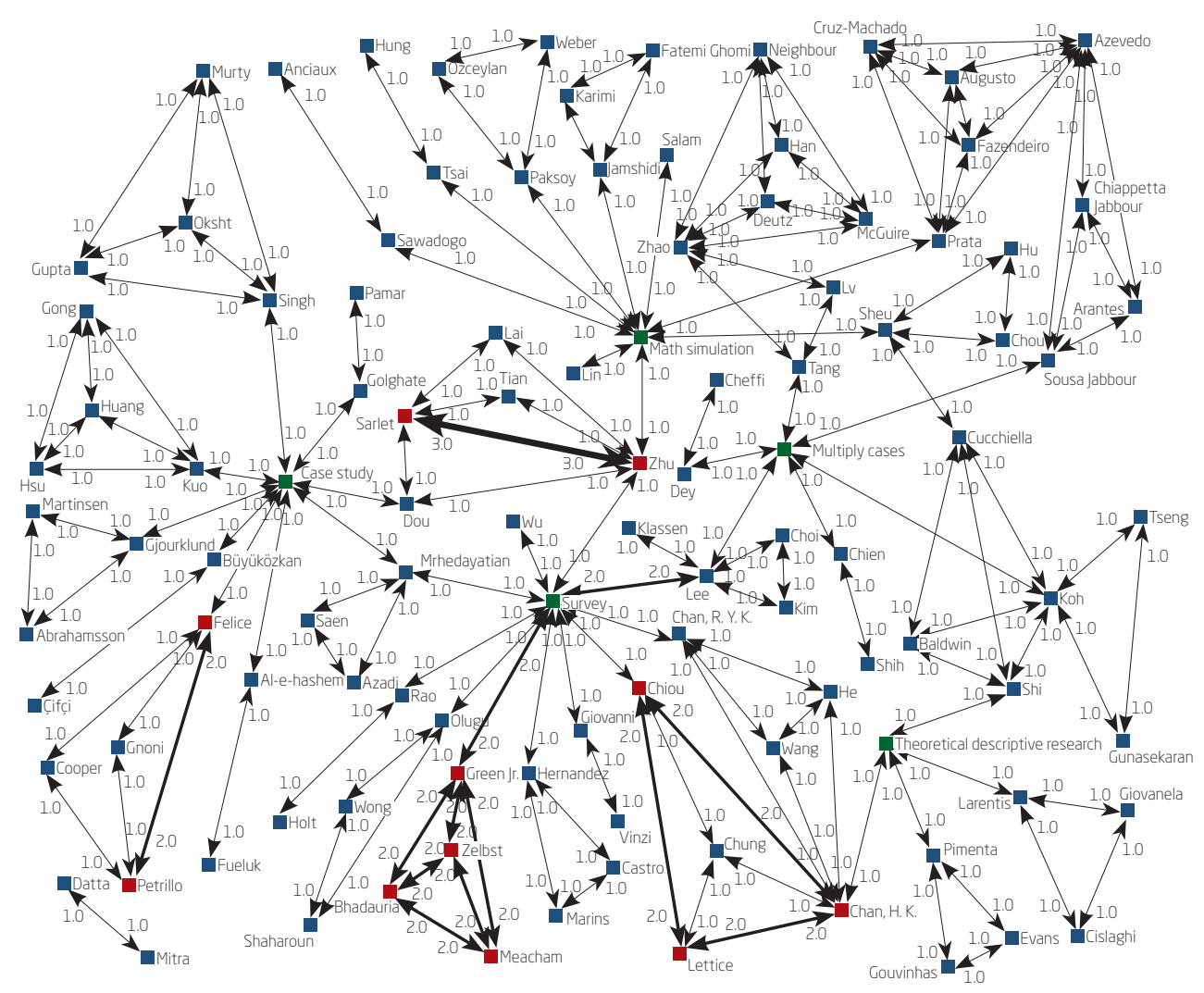

Source: Elaborated by the authors.

The relationships among authors and constructs addressed in the existing GSCM models are presented in Table 1 and Figure 2. In the analysis, it was possible to verify the constructs most used by the authors: GSCM internal practices (39 ties and DC: 11.017), Environmental performance (32 ties and DC: 9.040), GSCM external practices (24 ties and DC: 6.780), Economic performance (20 ties and DC: 5.650), Operational performance (10 ties and DC: 2.825$)$ as well as the least used constructs: Reverse logistics (nine ties and DC: 2.542), Green investments (seven ties and DC: 1.977), Eco-design (six ties and DC: 1.695), Corporate reactivity (five ties and DC: 1.412) and Corporate proactivity (one tie and DC: 0.282).

A proposition of the conceptual model is made with three hypotheses allowing for the possibility to study the relations of GSCM for performance 
improvement (environmental, economic and operational), and also if the green profile of companies can improve this relationship in item 4.4.

The aspects of GSCM, performance variables and profile variables of the companies addressed in the analyzed works on models and frameworks, are presented in Figure 3.

\section{(Figure 3)}

\section{AUTHORS' NETWORK IN RELATION TO CONSTRUCTS}

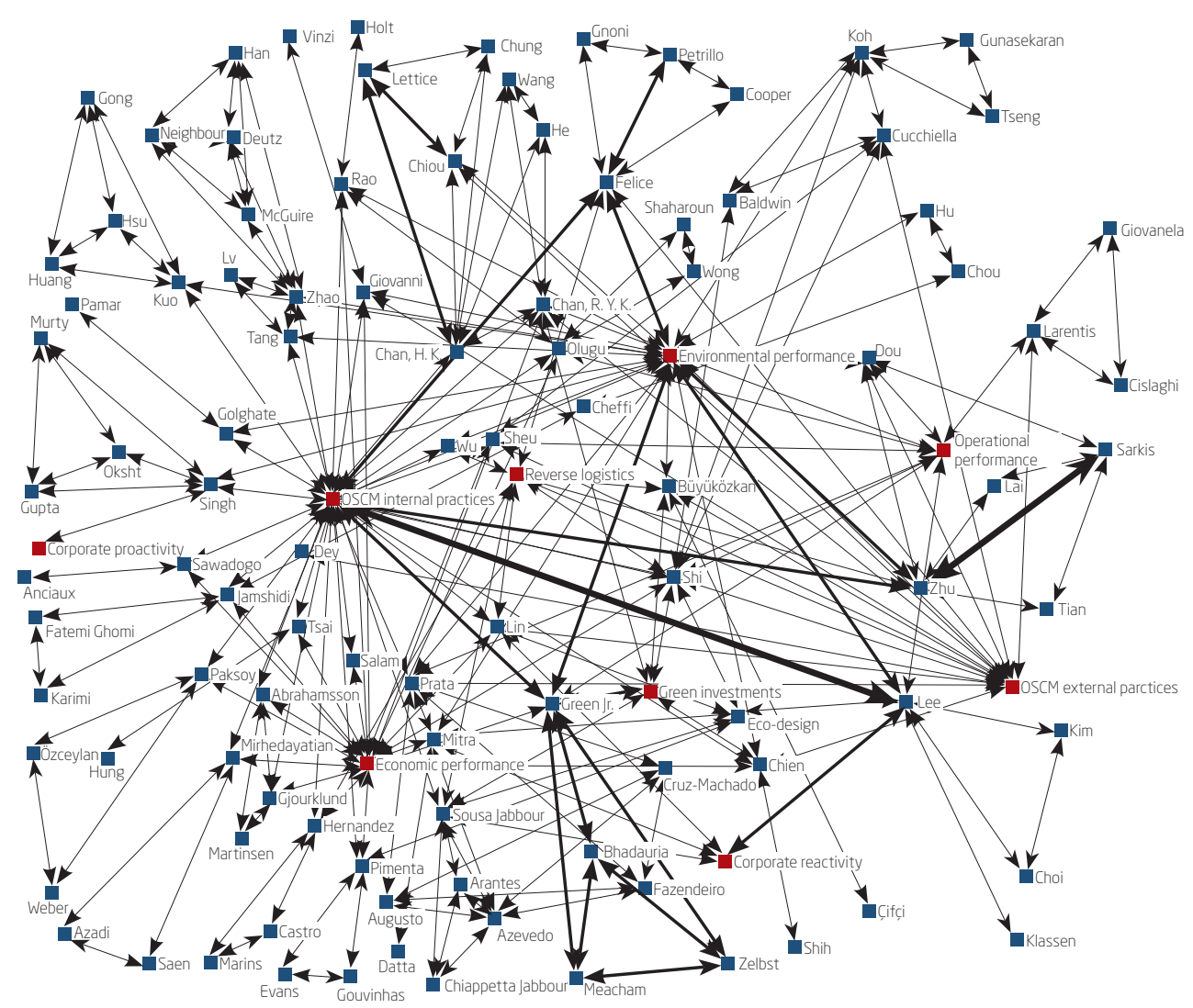

Source: Elaborated by the authors.

The indicators that measure GSCM internal and external practices were the most studied by authors that developed models/frameworks, in conjunction with the indicators of environmental and economic performance, while the green profile indicators of the companies were little studied, according to Figure 3. 


\subsection{GSCM VARIABLES CONSIDERED IN THE FRAMEWORKS}

Five important aspects of GSCM were observed in the analyzed works: GSCM internal and external practices, green investments, eco-design and reverse logistics. GSCM internal practices are related to the internal process of the management and manufacturing company. GSCM external practices are related to the "greening" of suppliers and participation of customers as well as the government in the decisions necessary for the operation of GSCM (Lin, 2013; Zhu et al., 2013). Green investments are the investments that may be needed right away to participate in GSCM. Eco-design is related to the "definition" from the process and product in the design phase when the raw materials are selected and define their performance (Zhu et al., 2013). Reverse logistics are related to the correct arrangement of the post-use product (Lin, 2013).

Thirty-nine models/frameworks that address GSCM internal practices have been observed: senior management commitment, support for mid-level managers and cross-functional cooperation for environmental improvement (Chan et al., 2012b; Dey \& Cheffi, 2012; Hernandez et al., 2012; Lee et al., 2012; Mitra \& Datta, 2014; Prata et al., 2013; Sheu et al., 2005; Zhu, Sarkis, \& Lai, 2012), total quality environmental management (Chan et al., 2012b; Giovanni \& Vinzi, 2012; Jabbour et al., 2013; Mirhedayatian et al., 2014; Mitra \& Datta, 2014; Tsai \& Hung, 2009), environmental compliance (Büyüközkan \& Çifçi, 2012; Felice et al., 2013; Hernandez et al., 2012; Kuo et al., 2013; Lee \& Klassen, 2008; Mirzapour Al-e-hashem \& Rekik, 2013; Olugu et al., 2011; Prata et al., 2013; Rao \& Holt, 2005; Salam, 2011; Shi et al., 2012; Tang et al., 2012), audit programmes (Jabbour et al., 2013; Mirhedayatian et al., 2014; Mitra \& Datta, 2014; Singh et al., 2008), ISO 14001 certification (Jabbour et al., 2013; Mirhedayatian et al., 2014; Singh et al., 2008), existing environmental management systems (Giovanni \& Vinzi, 2012; Green et al., 2012b; Jabbour et al., 2013; Wu, 2013), green manufacturing practice (Chien \& Shih, 2007; Dey \& Cheffi, 2012; Felice et al., 2012; Golghate \& Pawar, 2012; Green et al., 2012a; Mirhedayatian et al., 2014; Mitra \& Datta, 2014; Prata et al., 2013; Singh et al., 2008; Zhu et al., 2013), green purchases (Büyüközkan \& Çifçi, 2012; Chan et al., 2012a; Chan et al., 2012b; Chien \& Shih, 2007; Felice et al., 2012; Green et al., 2012a; Jabbour et al., 2013; Jamshidi et al., 2012; Lee, 2008; Lin, 2013; Mirzapour Al-e-hashem \& Rekik, 2013; Salam, 2011; Tsai \& Hung, 2009; Zhu et al., 2013) and reduction of emissions in transport (Bjourklund et al., 2012; Jamshidi et al., 2012; Mirhedayatian et al., 2014; Paksoy et al., 2011; Sawadogo \& Anciaux, 2011; Zhao et al., 2012). 
Twenty-four models/frameworks that used GSCM external practices have been found: provision of design specifications for suppliers (Chiou et al., 2011; Dey \& Cheffi, 2012; Dou et al., 2014; Felice et al., 2012; Green et al., 2012b; Lee \& Klassen, 2008; Mitra \& Datta, 2014; Wu, 2013), cooperation with suppliers for environmental objectives (Chiou et al., 2011; Dey \& Cheffi, 2012; Felice et al., 2012; Green et al., 2012b; Koh et al., 2012; Larentis et al., 2013; Lee, 2008; Lee et al., 2012; Lin, 2013; Prata et al., 2013; Rao \& Holt, 2005; Shi et al., 2012; Wu, 2013; Zhu, Sarkis \& Lai, 2012), audit of environmental management in suppliers (Green et al., 2012b), requirement of ISO 14001 certification of suppliers (Dou et al., 2014; Green et al., 2012b; Mitra \& Datta, 2014), cooperation with customers for eco-design (Chan et al., 2012a; Chien \& Shih, 2007; Felice et al., 2012; Green et al., 2012a; Koh et al., 2012; Lin, 2013; Olugu et al., 2011; Prata et al., 2013; Shi et al., 2012; Wu, 2013; Zhu, Sarkis \& Lai, 2012; Zhu et al., 2013), cooperation with customers and suppliers to implement cleaner production (Chien \& Shih, 2007; Giovanni \& Vinzi, 2012; Lin, 2013; Mitra \& Datta, 2014; Shi et al., 2012), environmentally correct packaging (Büyüközkan \& Çifçi, 2012; Felice et al., 2012; Giovanni \& Vinzi, 2012) and government participation (Lee, 2008; Lee, \& Klassen, 2008; Mitra \& Datta, 2014; Sheu et al., 2005; Zhu et al., 2013).

There were seven models/frameworks which addressed green investments, which is investment in equipment that reduces consumption of electricity, water and raw materials (Chien \& Shih, 2007; Green et al., 2012a; Shi et al., 2012; Wu, 2013) as well as activities that recover investments such as the sale of excess inventories of materials, scrap and used materials or depreciated equipment (Büyüközkan \& Çifçi, 2012; Chan et al., 2012a; Green et al., 2012a; Jabbour et al., 2013; Zhu et al., 2013).

Four models/frameworks were identified which deal with eco-design and reverse logistics together (Jabbour et al., 2013; Lin, 2013; Shi et al., 2012; Zhu et al., 2013), only two models used the eco-design construct alone (Green et al., 2012a; Pimenta et al., 2012) and five models used the reverse logistics construct alone (Büyüközkan \& Çifçi, 2012; Felice et al., 2012; Hernandez et al., 2012; Olugu et al., 2011; Sheu et al., 2005). For this study, it was decided to use eco-design and reverse logistics jointly: when the company invests in less aggressive raw materials to the environment, develops the design of its products to reduce the consumption of material and energy (Jabbour et al., 2013; Lin, 2013; Shi et al., 2012; Zhu et al., 2013), avoids the use of hazardous materials to the environment (Lin, 2013; Shi et al., 2012), acts together with its customers in the implementation of recycling, elimination of packaging and reduction of waste, and provides reverse logistics 
in the design of its products (Jabbour et al., 2013; Lin, 2013; Shi et al., 2012; Zhu et al., 2013).

\subsection{PERFORMANCE VARIABLES CONSIDERED IN THE FRAMEWORK}

Three aspects of performance have been considered in the articles surveyed: environmental, economic and operational.

Thirty-two models/frameworks which emphasized environmental performance have been identified: the companies which adopted GSCM reduced emissions of pollutants, use of waste water, solid waste and frequency of environmental accidents (Büyüközkan \& Çifçi, 2012; Chan et al., 2012b; Chien \& Shih, 2007; Chiou et al., 2011; Felice et al., 2012; Golghate \& Pawar, 2012; Jamshidi et al., 2012; Koh et al., 2012; Lin, 2013; Mitra \& Datta, 2014; Olugu et al., 2011; Sawadogo \& Anciaux, 2011; Sheu et al., 2005; Singh et al., 2008; Zhao et al., 2012) and improvement operating activities (Chan et al., 2012a; Chiou et al., 2011; Dey \& Cheffi, 2012; Dou et al., 2014; Felice et al., 2012; Felice et al., 2013; Giovanni \& Vinzi, 2012; Golghate \& Pawar, 2012; Green et al., 2012a; Green et al., 2012b; Kuo et al., 2014; Lee, 2008; Lee \& Klassen, 2008; Olugu et al., 2011; Prata et al., 2013; Rao \& Holt, 2005; Sheu et al., 2005; Shi et al., 2012; Tang et al., 2012; Wu, 2013; Zhu, Sarkis \& Lai, 2012; Zhu et al., 2013).

Twenty models/frameworks have been found that address economic performance, in which positive and negative results were considered; that is, positive if the company, when participating in GSCM, reduced the cost of energy and water consumption (Sawadogo \& Anciaux, 2011), decreased the rate of waste treatment and rate of waste discharge, increased reuse and recycling, decreased disposal of products and packaging (Hernandez et al., 2012; Jamshidi et al., 2012) and improved the profit margin (Bjourklund et al., 2012; Chan et al., 2012a; Chien \& Shih, 2007; Green et al., 2012a; Mirhedayatian et al., 2014; Mirzapour Al-e-hashem \& Rekik, 2013; Mitra \& Datta, 2014; Paksoy et al., 2011; Pimenta et al., 2012; Prata et al., 2013; Salam, 2011; Sheu et al., 2005; Tsai \& Hung, 2009). However, in relation to negative economic performance, the company increased investments to manufacture and market environmentally friendly products (Lin, 2013), operating costs increased (Olugu et al., 2011), cost of employee training increased to properly manage GSCM, costs rose due to the purchase of environmentally friendly materials, and spending on environmental awareness of customers, suppliers and society increased (Giovanni \& Vinzi, 2012; Rao $\&$ Holt, 2005). 
Ten models/frameworks that emphasized operational performance have been pointed out: by participating in GSCM, companies decreased the scrap rate, improved the quality of marketed products and services, improved the use of productive resources (Chan et al., 2012a; Dou et al., 2014; Green et al., 2012a; Larentis et al., 2013; Olugu et al., 2011; Prata et al., 2013; Zhu et al., 2013), achieved goals to minimize and eliminate product nonconformities (Green et al., 2012b; Lee et al., 2012; Sheu et al., 2005) and companies have improved the quality of customer complaint records, analysis and solutions (Chan et al., 2012a; Green et al., 2012a, b; Olugu et al., 2011).

\subsection{GREEN PROFILE VARIABLES CONSIDERED IN THE FRAMEWORKS}

Five models/frameworks which used corporate reactivity have been identified: environmental management is conditioned by the pressure of regulations, search for a better reputation (Lee, 2008; Lee \& Klassen, 2008) and pressure from shareholders, investors and banks so that companies reduce their environmental risk (Jabbour et al., 2013; Lin, 2013; Mitra \& Datta, 2014).

Only one model/framework that was addressed to corporate proactivity has been found: the environment must be considered in all decision making operations, and also if proactive companies have a capacity for prevention which includes planning, monitoring and anticipation, with systems to monitor and respond to internal and external environmental issues (Singh et al., 2008).

The GSCM internal practices (39 models/frameworks) have been the most observed in the models because companies always start environmental management by implanting the GSCM internal practices within the organizations and later extend control beyond the borders of the company as in, for example, suppliers demanding ISO 14001 certification and/or performing environmental auditing and the adoption of GSCM external practices (24 models/frameworks).

The green investments construct (seven models/frameworks) and eco-design and reverse logistics (four models/frameworks) are usually implanted in the later stages when the relations in GSCM are already more consolidated and the operations are run in a more rational way.

Economic performance is important, however, if it has been perceived that by improving operational performance (10 models/frameworks) such as reducing scrap and reducing waste, it is possible to simultaneously impro- 
ve both environmental (32 models/frameworks) and economic performance (20 models/frameworks).

\subsection{PROPOSAL OF CONCEPTUAL MODEL WITH HYPOTHESES}

The majority of the articles observed addressed the adoption of GSCM practices and performances, concluding that GSCM good practices positively affect performance. However, no evaluated article studied the influence of the company's green profile (reactive or proactive) in such a relationship. In addition, the vast majority of the work did not simultaneously address the three performance aspects (environmental, economic and operational).

The six models/frameworks have not made it clear whether companies that have a large green profile perform better than companies with only a reactive profile. Therefore, a wide field of future studies is open, and for this reason, indicators for the green profile construct are suggested as follows: 1. corporate reactivity: ensuring compliance with legislation (Ninlawan et al., 2010; Zhu \& Sarkis, 2004), minimizing the creation of environmental liabilities (Ninlawan et al., 2010) and increasing the environmental pressure of stakeholders (Zhu \& Sarkis, 2004); and 2. corporate proactivity: anticipating competitors in environmental issues (Porter \& Van der Linde, 1995), indicating the dedication of employees in environmental activities (Lau \& Ragothaman, 1997) and senior management giving high priority to environmental issues (Zhu \& Sarkis, 2004).

Based on these results, Hypothesis 1 (H1) is proposed: there is a significant positive relationship between the adoption of GSCM practices and their performance (environmental, economic and operational).

In addition to these results, the possible applications of the GSCM concept in the operations of companies are many and range from reactive reasons to regulations until the proactive strategies to obtain competitive advantage reasons, depending on the company's green profile (Sarkis, 1999). This initiative is distinct from environmental initiatives in which companies commit to improving their own environmental performance, respect, competitive advantage etc., and also, it happens due to the fact that stakeholders do not always draw a line between the focus of the company and its suppliers (Rao, 2002), making concern about suppliers' environmental performance characteristic of responsible business practice.

Thus, Hypothesis $2(\mathrm{H} 2)$ has been considered: there is a significant relationship between the company that performs proper management of the green supply chain and its green profile. 
The proactive approach of the corporate environment promotes the development of capabilities which, over time, helps to develop a better understanding of the problem and possible solutions needed to implement environmental solutions in operations and improve the channels of corporate communication with stakeholders (Sharma \& Vredenburg, 1998).

Therefore, Hypothesis 3 (H3) emerges: There is a significant relationship between the company's green profile on environmental issues and its performance (environmental, economic and operational).

Based on the review of the content in the existing models/frameworks, three hypotheses emerged in the conceptual model, according to Figure 4.

\section{(Figure 4)}

\section{GSCM PERFORMANCE EVALUATION MODEL}

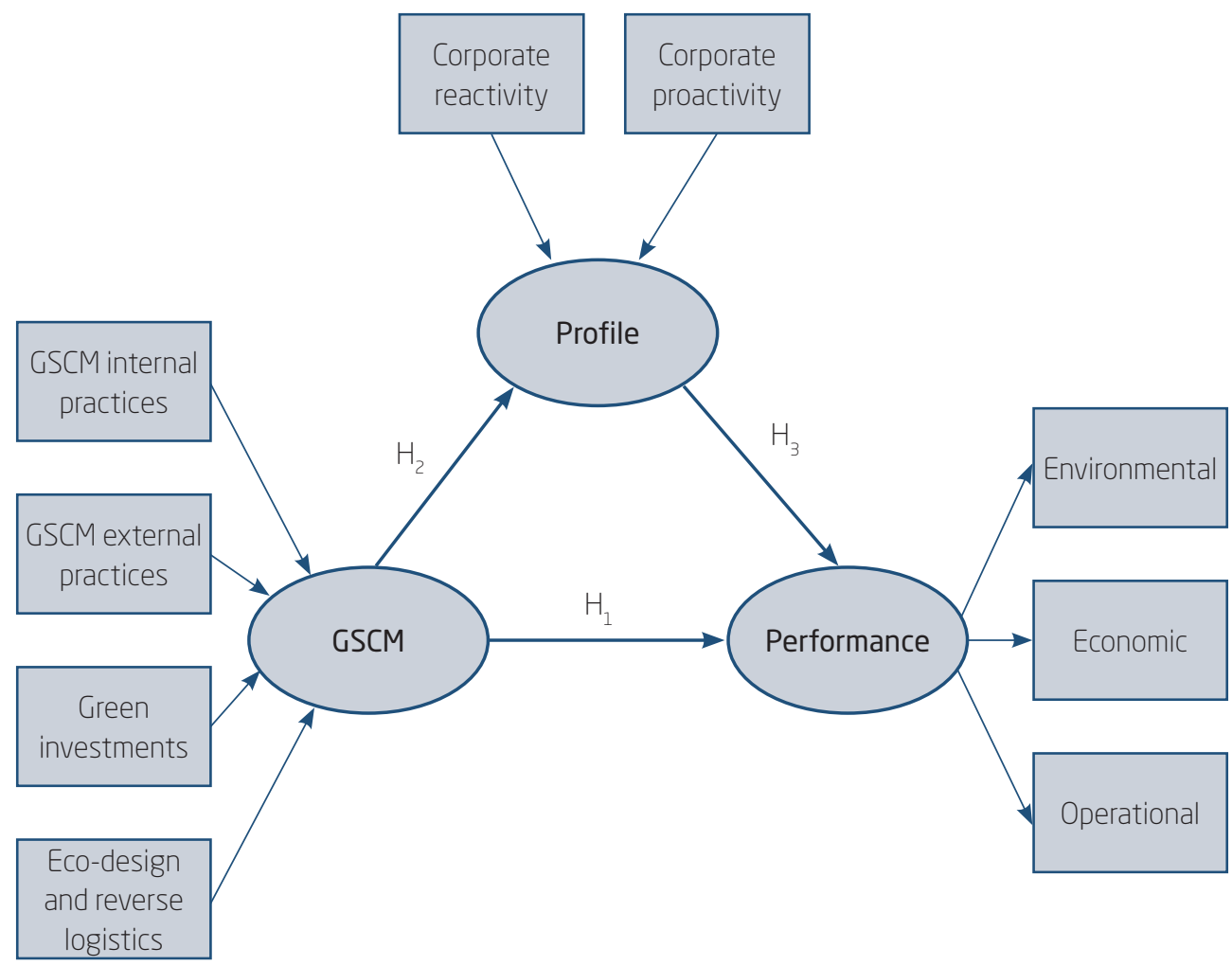

Source: Elaborated by the authors. 


\section{CONCLUDING REMARKS}

This paper aims to analyze the articles which have suggested models and frameworks of the relationship between GSCM and performance, as well as identify the constructs studied in the models and recommend a broad conceptual model that can be applied in future studies.

The results have revealed five important aspects of GSCM: GSCM internal and external practices, green investments, eco-design and reverse logistics. Most of the models which linked the eco-design and reverse logistics themes understood that when designing a product, the company should also consider the correct post-use destination of that product.

In the majority of the sampled articles, the internal practices of GSCM prevailed over the external ones. Green investments, eco-design and reverse logistics are still little studied; therefore, they represent a vast field of future research.

The models studied did not consider whether a corporate profile can improve the performance of an organization; therefore, they did not simultaneously measure environmental, economic and operational performance. They emphasized only one of the performances or in pairs. It has been concluded that the addition of the green profile variable together with GSCM practices and performance allows for a deeper analysis on the degree of commitment of the companies with GSCM, as well as their objectives and results to be achieved.

Finally, it was found that the models studied did not consider whether the corporate profile (reactive or proactive) could improve the performance of the organization.

Moreover, another finding of this work was that emerging economies, including that of Brazil, are economies which are trying to act within GSCM (Alberton \& Minatti, 2012a; 2012b; Chan et al., 2012a; 2012b; Felice, Petrillo, $\&$ Cooper, 2013) in order to improve business performance.

The limitation of this article was the conception of a broad conceptual model that has not yet been tested in practice through a survey, to confirm or adjust the model. Another limitation is that the model was developed based on research published until the year 2014. Suggested for future study are the analysis of existing research up to the current year and the development of a research instrument that can measure the constructs raised, as well as observing if the three hypotheses proposed can be confirmed. 


\section{PERFIL CORPORATIVO, DESEMPENHO E GREEN SUPPLY CHAIN MANAGEMENT: UMA AGENDA DE PESQUISA}

\section{RESUMO}

Objetivo: Avaliar o universo de artigos publicados que propuseram frameworks da relação entre green supply chain management (GSCM) e desempenho no período de 1995 à 2014, de modo a propor um modelo conceitual que possa ser aplicado para futuros estudos, considerando o perfil verde além das práticas de GSCM e desempenho.

Originalidade/lacuna/relevância/implicações: A investigação revelou a falta de relação entre o perfil verde das organizações, seu desempenho ambiental, econômico e operacional e as práticas de GSCM.

Principais aspectos metodológicos: A relação entre os constructos foi estabelecida por meio da análise bibliométrica nas bases de dados "ProQuest", "EBSCO", "JSTOR", "Web of Science" e "Scopus" sobre modelos/frameworks de práticas de GSCM e desempenho, análise de conteúdo e análise de redes.

Síntese dos principais resultados: Práticas internas e externas de GSCM, desempenho ambiental, desempenho econômico e desempenho operacional se revelaram como os principais temas abordados em GSCM, notou-se ainda que os estudos sobre práticas internas prevaleceram sobre aqueles que abordaram as demais práticas.

Principais considerações/conclusões: Os modelos estudados não consideraram se o perfil verde corporativo pode melhorar o desempenho da organização, tão pouco mensuraram simultaneamente o desempenho ambiental, econômico e operacional. Concluiu-se que o acréscimo da variável perfil verde das empresas em conjunto com as práticas de GSCM e desempenho permite uma análise em maior profundidade sobre o grau de envolvimento das empresas com a GSCM, bem como seus objetivos pretendidos e resultados a serem alcançados no futuro.

\section{PALAVRAS-CHAVE}

Bibliometria. Desempenho. Gestão da Cadeia de Suprimentos Verde. Modelo Conceitual. Perfil Verde. 


\section{PERFIL CORPORATIVO, EL RENDIMIENTO Y LA GESTIÓN DE LA CADENA DE SUMINISTRO VERDE: UN PROGRAMA DE INVESTIGACIÓN}

\section{RESUMEN}

Objetivo: Evaluar el universo de artículos publicados que proponían los marcos de la relación entre la gestión de la cadena de abastecimiento verde (GSCM) y el desempeño de 1995 a 2014 con el fin de proponer un modelo conceptual que se puede aplicar a los estudios futuros, teniendo en cuenta el perfil verde, así GSCM y el desempeño de la práctica.

Originalidad/laguna/relevancia/implicaciones: la investigación ha demostrado la falta de relación entre el perfil verde de las organizaciones, su desempeño ambiental, económica y operacional y las prácticas de GSCM. Principales aspectos metodológicos: la relación entre los constructos se estableció mediante el análisis bibliométrico en las bases de datos "ProQuest", "EBSCO", "JSTOR", "Web of Science" y "Scopus" en los modelos/frameworks GSCM prácticas y desempeño, análisis de contenido y análisis de redes.

Síntesis de los principales resultados: prácticas internas de GSCM, prácticas externas de GSCM, desempeño ambiental, desempeño económico y desempeño operativo demostrado que los principales temas tratados en GSCM, se observó que más estudios sobre las prácticas internas prevalecieron sobre los que se acercaban otras prácticas.

Principales consideraciones/conclusiones: los modelos estudiados no consideró si el perfil de color verde corporativo puede mejorar el rendimiento de la organización, tan poca medido simultáneamente el desempeño ambiental, económico y operativo. Se concluyó que la adición de la variable de perfil verde de las empresas, junto con las prácticas GSCM y de rendimiento permite un análisis en profundidad sobre el grado de implicación de las empresas con GSCM y sus objetivos y resultados que se pretende obtener en el futuro.

\section{PALABRAS CLAVE}

Bibliometría. Desempeño. Gestión de la cadena de suministro verde. Modelo Conceptual. Perfil verde. 


\section{REFERENCES}

ABNT. Associação Brasileira de Normas Técnicas. (2004). NBR ISO 14001: Sistemas da gestão ambiental - requisitos com orientações para uso.

ABNT. Associação Brasileira de Normas Técnicas. (2005). NBR ISO 14004: Sistemas de gestão ambiental: Diretrizes gerais sobre princípios, sistemas e técnicas.

Alberton, A., \& Minatti, C. (2012a). Green supply chain management: o caso da Metalúrgica Riosulense S.A. In Anais do Encontro Nacional de Engenharia de Produção, Bento Gonçalves, RS, Brasil, 32.

Alberton, A., \& Minatti, C. (2012b). Os 7R'S na indústria metal mecânica do Alto Vale do Itajaí, SC. In Anais do Encontro Nacional de Engenharia de Produção, Bento Gonçalves, RS, Brasil, 32.

Bardin, L. (1986). El análisis de contenido. Madrid: Ediciones Akal.

Borgatti, S. P. (2002). NetDraw: Graph visualization software. Harvard: Analytic Technologies.

Brazil. (2010). Presidency of Republic of Brazil, Civil House, Law no. 12.305. Establishing the National Policy on Solid Waste. August 2, 2010. In Official Document of Brazilian Union.

Brito, S. C., \& Aguiar, A. O. (2013). Relação entre o desenvolvimento de produtos verdes e as estratégias ambientais - um estudo de caso no setor de eletroeletrônicos. In Anais do Encontro Internacional sobre Gestão Empresarial e Meio Ambiente, São Paulo, SP, Brasil, 15. DOI: 10.11606/rai.v11i4.110246.

Buyukozkan, G., \& Gizem CifcI, G. (2012). A novel hybrid MCDM approach based on fuzzy DEMATEL, fuzzy ANP and fuzzy TOPSIS to evaluate green suppliers. Expert Systems with Applications. 39(3), 3000-3011. DOI: /10.1016/j.eswa.2011.08.162.

Bjorklund, M., Martinsen, U., \& Abrahamsson, M. (2012). Performance measurements in the greening of supply chains. Supply Chain Management: An International Journal. 17(1), 29-39. doi: 10.1108/13598541211212186.

Chan, R. Y. K., He, H., Chan, H. K., \& Wang, W. Y. C. (2012a). Environmental orientation and corporate performance: The mediation mechanism of green supply chain management and moderating effect of competitive intensity. Industrial Marketing Management, 41(4), 621-630. DOI: 10.1016/j. indmarman.2012.04.009. 
Chan, H. K., Chiou, T. Y., \& Lettice, F. (2012b). Research framework for analyzing the relationship between greening of suppliers and green innovation on firms' Performance. International Journal of Applied Logistics, 3(3), 22-36. DOI: $10.4018 /$ jal.2012070103.

Chien, M. K., \& Shih, L. H. (2007). An empirical study of the implementation of green supply chain management practices in the electrical and electronic industry and their relation to organizational performances. International Journal of Environment Science and Technology, 4(3), 383-394.

Chiou, T., Chan, H. K., Lettice, F., \& Chung, S. H. (2011). The influence of greening the suppliers and green innovation on environmental performance and competitive advantage in Taiwan. Transportation Research Part E, 47(6), 822-836. DOI: 10.1016/j.tre.2011.05.016.

Cordeiro, G. O., \& Drohomeretski, E. (2013). Gestão enxuta e ambiental da cadeia de suprimentos: análise das práticas na indústria automotiva. In Anais Simpósio de Engenharia de Produção, Bauru, SP, Brasil, 20.

Cooper, H. M., \& Lindsay, J. L. (1998). Research synthesis and meta-analysis. In: L. Bickman, \& D. J. Rog (Eds.), Handbook of applied social research methods. Thousand Oaks, CA: Sage.

Correira, T. J. M., Perim, M., Netto, Gonçalves, R. H., Duarte, P. C., \& Paes, R. L. (2012). Sistemática de diagnóstico da sustentabilidade da cadeia de suprimentos. In Anais do Encontro Nacional de Engenharia de Produção, Bento Gonçalves, RS, Brasil, 32.

De Nooy, W., Mrvar, A., \& Batagelj, V. (2005). Exploratory social network analysis with Pajek. New York: Cambridge University Press.

Dey, P. K., \& Cheffib, W. (2013). Green supply chain performance measurement using the analytic hierarchy process: a comparative analysis of manufacturing organizations. Production Planning \& Control, 24(8-9), 702-720. DOI: 10.1080/09537287.2012.666859.

Dou, Y., Zhu, Q., \& Sarkis, J. (2014). Evaluating green supplier development programs with a grey-analytical network process-based methodology. European Journal of Operational Research, 233(2), 420-431. DOI: 10.1016/j. ejor.2013.03.004.

Felice, F. D., Petrillo, A., \& Gnoni, M. G. (2012). An ANP-Based model for an effective Green Supply Chain Management. International Journal of Applied Logistics, 3(3), 1-14. DOI: 10.4018/jal.2012070101.

Felice, F. D., Petrillo, A., \& Cooper, O. (2013). An integrated conceptual model to promote green policies. International Journal of Innovation and Sustainable Development, 7(4), 333- 355. DOI: 10.1504/IJISD.2013.057037. 
Fiksel, J. Design for environment: creating eco-efficient products and processes. New York: McGraw-Hill, 1996. DOI:10.1162/jiec.1997.1.1.141.

Georges, M. R. R. (2013). Caracterização da Reciclamp como uma cadeia de suprimentos reversa e solidária. In Anais do Simpósio Internacional de Gestão de Projetos, Inovação e Sustentabilidade, São Paulo, SP, Brasil, 2.

Giovanni, P. D., \& Vinzi, V. E. (2012). Covariance versus component-based estimations of performance in green supply chain management. International Journal of Production Economics, 135(2). 907-916. DOI: 10.1016/j. ijpe.2011.11.001.

Golghate, C. D., \& Pawar, M. S. (2012). Green supply chain for plastic films: A framework for the coexistence of ecosystems and plastic industry for a better environment. International Journal of Sustainable Engineering, 5(1), 17-32. DOI: 10.1080/19397038.2011.609946.

Goto, A. K., Souza, M. T. S., \& Esteves, G. (2010). A certificação ambiental como garantia da cadeia de suprimentos verdes: um estudo no setor madeireiro. Anais do Encontro da Associação Nacional de Pós-Graduação e Pesquisa em Administração, Rio de Janeiro, RJ, Brasil, 34.

Green, K. W., Jr., Zelbst, P. J., Meacham, J., \& Bhadauria, V. S. (2012a). Green supply chain management practices: impact on performance. Supply Chain Management: An International Journal, 17(3), 290-305. DOI: 10.1108/13598541211227126.

Green, K. W., Jr., Zelbst, P. J., Bhadauria, V. S., \& Meacham, J. (2012b). Do environmental collaboration and monitoring enhance organizational performance? Industrial Management \& Data Systems, 112 (2), 186-205. DOI:10.1108/ 02635571211204254.

Hayes, A. F., \& Krippendorff, K. (2007). Answering the call for a standard reliability measure for coding data. Communication Methods and Measures, 1, 77-89. DOI: 10.1080/19312450709336664.

Henseler, J., Ringle, C., \& Sinkovics, R. R. (2009). The use of partial least squares path modeling in international marketing. New Challenges to International Marketing Advances. International Marketing, 20, 277-319.

Hernandez, C. T., Marins, F. A. S., \& Castro, R. C. (2012). Reverse Logistics Management Model. Gestão \& Produção, 19(3), 445-456. DOI: 10.1590/ S0104-530X2012000300001.

Ho, J. C., Shalishali, M. K., Tseng, T., \& Ang, D. S. (2009). Opportunities in green supply chain management. The Coastal Business Journal, 8(1), 18-31. 
Hoffman, A. J. (2000). Integrating environmental and social issues into corporate practice. Environment: Science and Policy for Sustainable Development, 42(5), 22-33. DOI: 10.1080/00139150009604887.

Hussey, D. M., \& Eagan, P. D. (2007). Using structural equation modeling to test environmental performance in small and medium-sized manufacturers: can SEM help SMEs? Journal of Cleaner Production, 15(4), 303-312. DOI: 10.1016/j.jclepro.2005.12.002.

Jabbour, A. B. L. S., Arantes, A. F., \& Jabbour, C. J. C. (2013). Gestão ambiental em cadeias de suprimentos: perspectivas atuais e futuras de pesquisa. Interciencia, 38(2), 104-111.

Jabbour, A. B. L. S., Azevedo, F. S., Arantes, A. F., \& Jabbour, C. J. C. (2013). Greening the supply chain: evidences of firms in Brazil. Gestão \& Produção, 20(4), 953-962. DOI: 10.1590/S0104-530X2013000400014.

Jabbour, A. B. L. S., \& Jabbour, C. J. C. (2012). Evolução da gestão ambiental e a adoção de práticas de green supply chain management no setor eletroeletrônico brasileiro. In Anais do Encontro da Associação Nacional de Pós-Graduação e Pesquisa em Administração, Rio de Janeiro, RJ, Brasil, 37.

Jabbour, A. B. L. S., Jabbour, C. J. C., Govindan, K., Kannan, D., \& Arantes, A. F. (2014). Mixed methodology to analyze the relationship between maturity of environmental management and the adoption of green supply chain management in Brazil. Resources, Conservation and Recycling, 92, 255-267. DOI: 10.1016/j.resconrec.2014.02.004.

Jamshidi, R., Ghomi, S. M. T. F., \& Karimi, B. (2012). Multi-objective green supply chain optimization with a new hybrid memetic algorithm using the Taguchi method. Scientia Iranica, 19(6), 1876-1886. DOI: 10.1016/j. scient.2012.07.002.

João, C. M., \& Barbieri, J. C. (2014a). A gestão sustentável em meios de hospedagem e sua cadeia de suprimentos - um estudo no litoral norte do Estado de São Paulo. In Anais do Simpósio de Administração da Produção; Logística e Operações Internacionais, São Paulo, SP, Brasil, 17.

João, C. M., \& Barbieri, J. C. (2014b). Sustentabilidade na cadeia de suprimentos dos meios de hospedagem do litoral norte de São Paulo. In Anais dos Seminários em Administração - FEA-USP, São Paulo, SP, Brasil, 17.

Klasses, R., \& McClaughlin, C. (1996). The impact of environmental management on firm performance. Management Science, 42(8), 1199-1214. DOI: $10.1287 /$ mnsc.42.8.1199. 
Koh, S. C. L., Gunasekaran, A., \& Tseng, C. S. (2012). Cross-tier ripple and indirect effects of directives WEEE and RoHS on greening a supply chain. International Journal of Production Economics, 140(1), 305-317. DOI: 10.1016/j. ijpe.2011.05.008.

Kuo, T., Hsu, C., Huang, S., \& Gong, D. (2014). Data sharing: a collaborative model for a green textile/clothing supply chain. International Journal of Computer Integrated Manufacturing, 27(3), 266-280. DOI: 10.1080/0951192X.2013.814157.

Larentis, F., Giovanella, R., \& Cislaghi, T. P. (2013). Sustainability in clusters: proposal of a conceptual model. Revista Ibero-Americana de Estratégia, 12(3), 212-241. DOI: 10.5585/riae.v12i3.1937.

Lau, R. S. M., \& Ragothaman, S. (1997). Strategic issues of environmental management. South Dakota Business Review, 56(2), 1-7.

Lee, S. (2008). Drivers for the participation of small and medium-sized suppliers in green supply chain initiatives. Supply Chain Management: An International Journal, 13(3), 185-198. DOI: 10.1108/13598540810871235.

Lee, S., \& Klassen, R. D. (2008). Drivers and enablers that foster environmental management capabilities in small and medium-sized suppliers in supply chains. Production and Operations Management, 17(6), 573-586. DOI: 10.3401/poms.1080.0063.

Lee, S. M., Kim, S. T., \& Choi, D. (2012). Green supply chain management and organizational performance. Industrial Management \& Data Systems, 112(8), 1148-1180. DOI: 10.1108/02635571211264609.

Leite Filho, G. A. (2006). Padrões de produtividade de autores em periódicos e congressos na área de contabilidade no Brasil: um estudo bibliométrico. In Anais do Congresso USP de Controladoria e Contabilidade, São Paulo, SP, Brasil, 6. Lin, R. J. (2013). Using fuzzy DEMATEL to evaluate the green supply chain management practices. Journal of Cleaner Production, 40, 32-39. DOI: 10.1016/j.jclepro.2011.06.010.

Lopes, L. J., Sacomano, M., Neto, Silva, E. M., \& Lopes, F. C. C. (2013). Influência das práticas do green supply chain management no desempenho ambiental das empresas do setor automotivo brasileiro. In Anais do Encontro da Associação Nacional de Pós-Graduação e Pesquisa em Administração, Rio de Janeiro, RJ, Brasil, 37.

Mauricio, A. L., Franscareli, F. C. O., \& Jabbour, A. B. L. S. (2013). Adoção de práticas de green supply chain management e suas implicações no desempenho ambiental e operacional: estudo de casos no setor de baterias automotivas. In Anais do Simpósio de Engenharia de Produção, Bauru, SP, Brasil, 20. 
Mentzer, J. T., DeWitt, W., Keebler, J. S., Min, S., Nix, N. W., Smith, C. D., \& Zacharia, Z. G. (2001). Defining supply chain management. Journal of Business logistics, 22(2), 1-25. DOI: 10.1002/j.2158-1592.2001.tb00001.x.

Mirhedayatian, S. M., Azadi, M., \& Saen, R. F. (2014). A novel network data envelopment analysis model for evaluating green supply chain management. International Journal of Production Economics, 147(Part B), 544-554. DOI:10.1016/j.ijpe.2013.02.009.

Mirzapour Al-e-hashem, S. M. J., \& Rekik, Y. (2013). Multi-product multi-period Inventory Routing Problem with a transshipment option: A green approach. International Journal of Production Economics, 157, 80-88. doi:10.1016/j.ijpe.2013.09.005.

Mitra, S., \& Datta, P. P. (2014). Adoption of green supply chain management practices and their impact on performance: an exploratory study of Indian manufacturing firms. International Journal of Production Research, 52 (7), 2085-2107. DOI: 10.1080/00207543.2013.849014.

Moori, R. G., Shibao, F. Y., \& Kimura, H. (2013). O efeito moderador da motivação ambiental sobre o desempenho da cadeia de suprimentos verde das empresas químicas. In Anais do Encontro da Associação Nacional de Pós-Graduação e Pesquisa em Administração, Rio de Janeiro, RJ, Brasil, 37.

Ninlawan, C., Seksan, P., Tossapol, K., \& Pilada, W. (2010, March). The implementation of green supply chain management practices in electronics industry. In Proceedings of the international multi-conference of engineers and computer scientists, (v. 3, pp. 17-19), Hong Kong, China.

Olugu, E. U., Wong, K. Y., \& Shaharoun, A. M. (2011). Development of key performance measures for the automobile green supply chain. Resources, Conservation and Recycling, 55(6), 567-579. DOI:10.1016/j.resconrec.2010.06.003. Paksoya, T., Zceylana, E., \& Weber, G. (2011). A multi objective model for optimization of a green supply chain network. Global Journal of Technology \& Optimization. 2(1), 1-13. DOI: 10.1063/1.3459765.

Pimenta, H. C. D., Gouvinhas, R. P., \& Evans, S. (2012). Eco-efficiency within extended supply chain. Holos, 28(1), 73-85. DOI: 10.15628/holos.2012.866.

Porter, M. E., \& Van der Linde, C. (1995). Green and Competitive: ending the stalemate. Harvard Business Review, 73(5), 121-134.

Prata, P., Fazendeiro, P., Augusto, C., Azevedo, S., \& Cruz-Machado, V. (2013). Ambiente Colaborativo para Avaliação de Cadeias de Abastecimento. Iberian Journal of Information Systems and Technologies, 12, 1-15. DOI: 10.4304/risti.12.1-15. 
Rao, P. (2002). Greening the supply chain: a new initiative in South East Asian context. International Journal of Operations \& Production Management, 22(5/6), 632-655. DOI: 10.1108/01443570210427668.

Rao, P., \& Holt, D. (2005). Do green supply chains lead to competitiveness and economic performance? International Journal of Operations \& Production Management, 25(9), 898-916. DOI: 10.1108/01443570510613956.

Salam, M. A. (2011). Creating sustainable supply chain through green procurement. International Journal of Business Insights \& Transformation, 3 (3), 84-89. Santos, L. B., Vanalle, R. M., \& Lucato, W. C. (2011). Inserção de práticas de sustentabilidade ambiental como requisitos no processo de seleção de fornecedores: um estudo de caso. In Anais do Encontro Nacional de Engenharia de Produção, Belo Horizonte, MG, Brasil, 31.

Santos, R. M. B., Oliveira, R. S., \& Silva, J. C. L. Filho. (2010). Logística reversa no setor de alimentos perecíveis: a perspectiva de elos da cadeia reversa. In Anais do Encontro Internacional de Gestão e Meio Ambiente, São Paulo, SP, Brasil, 12.

Sarkis, J. (1999). How Green is the Supply Chain? Practice and research. Worcester: Graduate School of Management, Clark University.

Sarkis, J., Zhu, Q., \& Lai, K. (2011). An organizational theoretic review of green supply chain management literature. International Journal of Production Economics, 130(1), 1-15. DOI: 10.1016/j.ijpe.2010.11.010.

Sawadogo, M., \& Anciaux, D. (2011). Intermodal transportation within the green supply chain: an approach based on the ELECTRE method. International Journal of Business Performance and Supply Chain Modeling, 3(1), 43-65. DOI: 10.1504/IJBPSCM.2011.039973.

Seuring, S., \& Müller, M. (2008). From a literature review to a conceptual framework for sustainable supply chain management. Journal of Cleaner Production, 16(15), 1699-1710. DOI: 10.1016/j.jclepro.2008.04.020.

Sharma, S., \& Vredenburg, H. (1998). Proactive corporate environmental strategy and the development of competitively valuable capabilities. Strategic Management Journal, 19(8), 729-753.

Sheu J., Chou, Y., \& Hu, C. (2005). An integrated logistics operational model for green- supply chain management. Transportation Research Part E, 41 (4), 287-313. DOI:10.1016/j.tre.2004.07.001.

Shi, V. G., Ko, S. C. L., Baldwin, J., \& Cucchiella, F. (2012). Natural resource based green supply chain management. Supply Chain Management: An International Journal, 17(1), 54-67. DOI: 10.1108/13598541211212203. 
Shibao, F. Y. (2011). Cadeia de suprimentos verde: um estudo nas indústrias químicas no Brasil. Tese de doutorado, Universidade Presbiteriana Mackenzie, São Paulo, SP, Brasil.

Shibao, F. Y., Moori, R. G., Santos, M. R., \& Oliveira, G. C., Neto. (2013). A cadeia de suprimentos verde e as indústrias químicas no Brasil. In Anais dos Seminários em Administração FEA-USP, São Paulo, SP, Brasil, 16.

Shibao, F. Y., \& Santos, M. R. (2013). Um comparativo entre práticas da gestão da cadeia de suprimentos verde chinês, japonês e brasileiro. In Anais do Encontro da Associação Nacional de Pós-Graduação e Pesquisa em Administração, Rio de Janeiro, RJ, Brasil, 37.

Silva, T. H. H., \& Dias, T. (2014). Fatores motivadores e dificultadores para adoção do gerenciamento da cadeia de suprimentos verde em organizações do setor elétrico. In Anais do Simpósio Internacional de Gestão de Projetos, Inovação e Sustentabilidade, São Paulo, SP, Brasil, 3.

Singh, R. K., Murty, H. R., Gupta, S. K., \& Dikshit, A. K. (2008). Integrated environment management in steel industries. International Journal of Management and Decision Making, 9(2), 103-128. DOI: 10.1504/IJMDM.2008.017194. Srivastava, S. K. (2007). Green supply chain management: a state-of-theart literature review. International Journal of Management Reviews, 9(1), 53-80. DOI: $10.1111 /$ j.1468-2370.2007.00202.x.

Tang, Q., Zhao, S., \& Lv, X. (2012). On Performance Evaluation of Green Supply Chain Based on Cloud-Matter Element Model. Journal of Chongqing Jiaotong University (Natural Science), 30(2), 340-343.

Teixeira, I. G. R., Calia, R. C., \& Neves, M. F. (2012). Construindo a cadeia de suprimentos do futuro: um estudo de caso do Walmart Brasil. In Anais do Encontro Internacional sobre Gestão Empresarial e Meio Ambiente, São Paulo, SP, Brasil, 14.

Tsaia, W. H., \& Hungb, S. (2011). A fuzzy goal programming approach for green supply chain optimization under activity-based costing and performance with a value-chain structure. International Journal of Production Research, 47(18), 4991-5017. DOI: 10.1080/00207540801932498.

Vachon, S., \& Klassen, R. D. (2008). Environmental management and manufacturing performance: The role of collaboration in the supply chain. International Journal of Production Economics, 111 (2), 299-315. DOI: 10.1016/j. ijpe.2006.11.030.

Wang, H., \& Gupta, S. M. (2011). Green Supply Chain Management: Product Life Cycle Approach. New York, USA: McGraw Hill. DOI: 10.1080/00207543. 2011.644657. 
Wasserman, S., \& Faust, K. (1994). Social network analysis: Methods and applications. Cambridge, UK: Cambridge University Press.

$\mathrm{Wu}, \mathrm{G}$. (2013). The influence of green supply chain integration and environmental uncertainty on green innovation in Taiwan's IT industry. Supply Chain Management: An International Journal, 18(5), 539-552. DOI: 10.1108/ SCM-06-2012-0201.

Zhao, R., Neighbour, G., Han, J., McGuire, M., \& Deutz, P. (2012). Using game theory to describe strategy selection for environmental risk and carbon emissions reduction in the green supply chain. Journal of Loss Prevention in the Process Industries, 25(6), 927-936. DOI: 10.1016/j.jlp.2012.05.004.

Zhu, Q., Geng, Y., Fujita, T., \& Hashimoto, S. (2010). Green supply chain management in leading manufacturers: Case studies in Japanese large companies. Management Research Review, 33(4), 380-392. DOI: 10.1108/01409171011030471.

Zhu, Q., \& Sarkis, J. (2004). Relationships between operational practices and performance among early adopters of green supply chain management practices in Chinese manufacturing enterprises. Journal of operations management, 22 (3), 265-289. DOI: 10.1016/j.jom.2004.01.005.

Zhu, Q., Sarkis, J., \& Lai, K. (2007). Initiatives and outcomes of Green supply chain management implementation by Chinese manufacturers. Journal of Environmental Management, 85(1), 179-189. DOI: 10.1016/j.jenvman.2006.09.003. Zhu, Q., Sarkis, J., \& Lai, K. H. (2008). Confirmation of a measurement model for green supply chain management practices implementation. International Journal of Production Economics, 111 (2), 261-273. DOI: 10.1016/j. ijpe.2006.11.029.

Zhu, Q., Sarkis, J., \& Lai, K. H. (2012). Examining the effects of green supply chain management practices and their mediations on performance improvements. International Journal of Production Research, 50(5), 1377-1394. DOI:10. 1080/00207543.2011.571937.

Zhu, Q., Sarkis, J., \& Lai, K. (2013). Institutional-based antecedents and performance outcomes of internal and external green supply chain management practices. Journal of Purchasing \& Supply Management, 19(2), 106-117. DOI: $10.1016 /$ j.pursup.2012.12.001.

Zhu, Q., Tian, Y., \& Sarkis, J. (2012). Diffusion of selected green supply chain management practices: an assessment of Chinese enterprises. Production Planning \& Control: The Management of Operations, 23(10-11), 837-850. DOI: 10.1080/09537287.2011.642188. 